\title{
Effects of the substitution of soybean meal by spirulina in a hay-based diet for dairy cows on milk composition and sensory perception
}

\author{
E. Manzocchi, ${ }^{1}$ B. Guggenbühl, ${ }^{2}$ M. Kreuzer, ${ }^{1}$ (1) and K. Giller ${ }^{1 *}$ (1) \\ ${ }^{1}$ ETH Zurich, Institute of Agricultural Sciences, Universitaetstrasse 2, 8092 Zurich, Switzerland \\ ${ }^{2}$ Agroscope, Federal Department of Economic Affairs, Education and Research, Schwarzenburgstrasse 161, 3003 Bern, Switzerland
}

\begin{abstract}
The demand for protein sources alternative to soybean meal for supplementing forages low in metabolizable protein is large. The suitability of spirulina (Arthrospira platensis), a fast growing and resource-efficient blue-green microalga, as a source of metabolizable protein for dairy cows is known, but its effects on milk antioxidants and sensory properties were never investigated. Twelve cows were allocated to 2 groups and fed hay-based diets complemented with sugar beet pulp and wheat flakes in individual feeding troughs. The $\mathrm{N}$ content per kilogram of DM was equivalent between the 2 diets. Diet of 1 group was supplemented with $5 \%$ spirulina; the second group was supplemented with $6 \%$ soybean meal (control). After an adaptation period of $15 \mathrm{~d}$, data were collected, and feed, milk, blood, and rumen fluid were sampled. Feeds were analyzed for proximate contents, and blood plasma was analyzed for total antioxidant capacity and antioxidant contents (tocopherol, phenols). Milk samples were analyzed for fatty acid profile, coagulation properties, color, and contents of fat, protein, lactose, total phenols, lipophilic vitamins, and provitamins (e.g., $\beta$-carotene). Triangle tests were performed by a trained sensory panel on 6 homogenized and pasteurized bulk milk samples per treatment. The substitution of soybean meal by spirulina in the diet did not affect feed intake, milk yield, milk fat, protein, or lactose contents compared with the control group. However, the milk from the spirulina-fed cows had a higher content of $\beta$-carotene (0.207 vs. $0.135 \mu \mathrm{g} / \mathrm{mL}$ ) and was more yellow (b* index: 14.9 vs. 13.8). Similar to the spirulina lipids but far less pronounced, the milk fat from the spirulina-fed cows had a higher proportion of $\gamma$-linolenic acid (0.057 vs. $0.038 \%$ of fatty acid methyl esters) compared with milk fat from soybean meal-fed cows. Also trans-11 C18:1 (vaccenic acid) and other C18:1 trans isomers were elevated, but otherwise
\end{abstract}

Received March 27, 2020.

Accepted July 27, 2020.

*Corresponding author: katrin.giller@usys.ethz.ch the fatty acid profile resembled that of cows fed the control diet. No sensory difference was found between milk from the 2 experimental groups. Furthermore, we observed no effects of substituting soybean meal by spirulina on total antioxidant capacity, $\alpha$-tocopherol and total phenols in blood and milk. Effects on rumen fluid characteristics were minor. In conclusion, spirulina seems to be a promising protein source for dairy cows with certain improvements in nutritionally favorable constituents in milk and without side-effects on animal performance in the short term.

Key words: dairy cattle, Arthrospira platensis, fatty acid, sensory quality, $\beta$-carotene

\section{INTRODUCTION}

The biomass of the cyanobacterium Arthrospira platensis, commonly referred to as spirulina and associated with the group of the microalgae, is a promising protein source which may represent an alternative to soybean meal in dairy cows' diets. Different from soybeans, spirulina can be produced with high water efficiency (Habib et al., 2008) on marginal land or even landless, and therefore does not compete for land with human food resources. Spirulina is already used as a nutraceutical in human nutrition and as feed supplement in animal nutrition, especially in aquaculture and poultry production (Wan et al., 2016). It is estimated that by 2054, alternative protein sources will account for $33 \%$ of the global total protein consumption, with $56 \mathrm{Mt}$ of algae being consumed annually (Probst et al., 2015). Already today, $50 \%$ of the produced spirulina biomass is used in the nutrition of livestock, including cattle (Bleakley and Hayes, 2017).

To our knowledge, only few studies evaluated spirulina as a diet ingredient for dairy cows. Lamminen et al. (2019b) showed that the protein value of spirulina is slightly lower than that of rapeseed meal in a grass silage-based diet. Furthermore, previous studies reported a reduced palatability through the inclusion of microalgae in concentrate feeds and TMR diets (Moate et al., 2013; Lamminen et al., 2019a,b). Supplement- 
ing grazing cows with a low amount (15 and $30 \mathrm{~g} / \mathrm{d}$ ) of spirulina during the transition period did not affect BW, BCS, milk yield, composition, SCC, and total antioxidant capacity in blood in the subsequent lactation (Garcés et al., 2018). Recently, Till et al. (2019) reported that the supplementation of dairy cows with up to $150 \mathrm{~g} / \mathrm{d}$ of another microalgae, Schizochytrium limacinum, reduced the SFA proportion in milk and cheese as well as the n-6 to n-3 FA ratio. It also increased nutty flavor and fruity odor, increased the astringency, and decreased the creaminess of a cheddar-type cheese. It seems unlikely that these results can be generalized for all microalgae in dairy cows' diets, especially because FA and antioxidant profiles substantially differ between the microalgae. Therefore, the resulting milk might be differently susceptible to oxidation and off-flavors. Further, it has to be clarified if the effects of spirulina are different when provided in higher amounts and to a diet with lower proportions of antioxidant compounds than those present in fresh herbage, such as in hay. In this regard, the content of phenols in spirulina and their potential effects on blood and milk antioxidant capacity were never reported in literature. The potential benefits of spirulina might also include an improvement of animal health, as it is a good source of micronutrients and antioxidants such as carotenoids, tocopherols, and phenolic acids (Becker, 2013). In contrast to other microalgae, the spirulina lipids are not characterized by high proportions of nutritionally favorable n-3 FA, but by n- 6 FA, especially C18:3n-6 (Sajilata et al., 2008) and saturated FA. C18:3n-6 ( $\gamma$-linolenic acid, GLA) is of special nutritional interest (Fan and Chapkin, 1998), and it is typically rare in dairy cow's milk, although it is more prevalent in yak milk (Ding et al., 2013). The characteristic FA profile of spirulina might, however, be reflected in milk only to a limited degree due to the substantial ruminal biohydrogenation of PUFA. Overall it is likely that spirulina feeding will alter the nutritional properties of the milk (Becker, 2013), but whether or not the favorable effects outweigh possible unfavorable effects still has to be demonstrated.

Therefore, the present research aimed at evaluating the effect of substituting soybean meal completely by $5 \%(850 \mathrm{~g} / \mathrm{d})$ of spirulina in a hay-based diet for dairy cows on the feed intake, milk yield, and milk quality. The latter comprised variables concerning nutritional characteristics, coagulation properties, and sensory perception. We tested the following hypotheses: (1) feed intake is negatively affected by the rather high level of spirulina; (2) the spirulina alters milk composition inclusive of FA profile and $\beta$-carotene content, with consequences for milk coagulation properties; (3) the contents of compounds with antioxidant properties, such as phenolic compounds in milk, and the milk's antioxidant capacity are higher with supplemented spirulina; and (4) these compounds compensate for adverse effects of the altered FA profile on the milk's sensory properties.

\section{MATERIALS AND METHODS}

\section{Animals and Diets}

The experiment was approved by the cantonal veterinary office in Zurich, Switzerland (license no. ZH125/18). Twelve late-lactating dairy cows were assigned in a randomized manner to 2 diets balanced by breed (3 Brown Swiss and 3 Holstein per group), parity (2 primiparous and 4 multiparous per group), DIM, and milk yield. The initial average milk yields of the cows fed spirulina and control were $25.8 \pm 2.04 \mathrm{~kg} / \mathrm{d}$ and $25.8 \pm 2.17 \mathrm{~kg} / \mathrm{d}$, respectively, and DIM at the start of the experiment was $331 \pm 27$ and $326 \pm 34$. Average fat and protein contents were $4.66 \pm 0.557 \%$ and $3.85 \pm 0.358 \%$, respectively. At the beginning of the experiment, the spirulina and control cows weighed $718 \pm 38.5 \mathrm{~kg}$ and $693 \pm 23.0 \mathrm{~kg}$, respectively. The experimental period lasted for $33 \mathrm{~d}$ in total and was divided into an adaptation period ( $15 \mathrm{~d})$ and a sampling period $(18 \mathrm{~d})$. The pre-experimental diet consisted of a TMR (grass silage, maize silage, alfalfa hay, hay, soybean meal, and vitaminized mineral premix) and up to $5 \mathrm{~kg} / \mathrm{d}$ of concentrate feed to cover requirements for maintenance and milk yield according to Agroscope (2020). At the start of the adaptation period, this preexperimental diet was replaced by the experimental diets. The complete diets were equivalent in $\mathrm{ME}$ content and isonitrogenous ( $24 \mathrm{~g}$ of $\mathrm{N} / \mathrm{kg}$ of $\mathrm{DM}$ ). From $\mathrm{d} 3$ onward, the cows no longer received extra concentrate. The control diet consisted, on a DM basis, of a TMR with $74 \%$ hay (second cut, ryegrass-clover mixture), $13 \%$ sugar beet pulp, $6 \%$ soybean meal, $4 \%$ wheat flakes and $3 \%$ molasses. In the spirulina diet, soybean meal was replaced by $5 \%$ spirulina (Institut für Getreideverarbeitung, Nuthetal, Germany) and 1\% wheat flakes, resulting in a diet composed of $74 \%$ hay, $13 \%$ sugar beet pulp, $5 \%$ spirulina, $5 \%$ wheat flakes, and $3 \%$ molasses. The forage-to-concentrate ratio was 74:26 in both diets. The spirulina had been cultivated in production ponds in a Spirulina-Ogawa-Terui medium as designed by Ogawa and Terui (1970), harvested, vacuum belt filtered, spray dried, and eventually sifted and blended at the Institut für Getreideverarbeitung (Nuthetal, Germany). Before mixing of the complete diets once per day, the sugar beet pulp pellets were soaked for $2 \mathrm{~h}$ in water (1:4). The respective protein source (soybean meal or spirulina powder) and the wheat flakes were mixed with the soaked sugar beet pulp, added to the 
hay and molasses in a mixing truck and mixed homogeneously to avoid feed selection. The spirulina powder was previously mixed with water (1:10). The cows also received $50 \mathrm{~g} / \mathrm{d}$ of $\mathrm{NaCl}$ and $120 \mathrm{~g} / \mathrm{d}$ of a vitaminized mineral mix. This mix contained per kilogram: $80 \mathrm{~g} \mathrm{Ca}$; 160 g P; 50 g Mg; 45 g Na; 4 g Zn; 2 g Mn; 0.5 g Cu; $0.02 \mathrm{~g}$ Se; $0.02 \mathrm{~g} \mathrm{I}$; $0.015 \mathrm{~g}$ Co, as well as, per kilogram, vitamin $\mathrm{A}, 1,200,000 \mathrm{IU}$; vitamin $\mathrm{D}_{3}, 200,000 \mathrm{IU}$; vitamin E, $2 \mathrm{~g}$. The 12 cows were housed as a group in a loose housing system. Milking took place at 0500 and $1600 \mathrm{~h}$ in a tandem milking parlor. Diets were offered at 0530 and $1630 \mathrm{~h}$ in individual troughs accessible only by the respective animal via transponder. The cows had ad libitum access to feed and water. In the sampling period, feed supply and refusals, milk yield, and BW (after morning milking) were recorded daily.

\section{Feed Sampling and Analysis}

Samples of each diet component were collected before the start of the experiment and on d 1, 6, 12, and 18 of the sampling period. Samples of the mixed diets were collected every third day during the sampling period. Feed samples were dried $\left(60^{\circ} \mathrm{C}, 48 \mathrm{~h}\right)$ and milled to pass through a 1-mm screen. Contents of DM and total ash were analyzed by a TGA-701 furnace (Leco, St. Joseph, MI; AOAC International, 1997, index no. 942.05). The OM was calculated as the difference between DM and total ash. Gross energy content was determined by bomb calorimetry (Calorimeter C7000 with Cooler C7002, IKA-Werke GmbH \& Co. KG, Staufen, Germany). The detergent fiber fractions NDF, ADF, and ADL were analyzed on a Fibertherm FT 12 (Gerhardt, Königswinter, Germany) according to Van Soest et al. (1991) with the addition of heat-stable amylase, without sodium sulfite, in FiberBags with a pore size of $30 \mu \mathrm{m}$ (Gerhardt, Königswinter, Germany). This was not possible for the very fine spirulina powder alone, as reported also by Wild et al. (2018) and Lamminen et al. (2017, 2019a). Fiber fractions were expressed without residual ash. Hemicellulose and cellulose were calculated as the differences between NDF and ADF as well as between ADF and ADL, respectively. The ether extract (EE) was determined with a Soxhlet extractor (Extraction System B-811, Büchi, Flawil, Switzerland; AOAC International, 1997, index no. 963.15). The $\mathrm{N}$ content was analyzed with a $\mathrm{C} / \mathrm{N}$ analyzer (TruMac CN, Leco; AOAC International, 1997, index no. 968.06). The $\mathrm{CP}$ content was calculated as $6.25 \times \mathrm{N}$. Nonfiber carbohydrates were calculated as the difference between the $\mathrm{OM}$ and the sum of $\mathrm{CP}$, EE, and NDF. All further analyses were carried out only in the samples of the complete diets and the spirulina. Total extractable phenols, nontannin phenols, and condensed tannins were analyzed by the Folin-Ciocalteau method as described by Jayanegara et al. (2012). Total tannins were calculated as the differences of total extractable phenols and nontannin phenols. Hydrolyzable tannins were calculated as the difference between total tannins and condensed tannins. The content of $\beta$-carotene was analyzed with a normal-phase UV/VIS HPLC (La Chrom, Merck-Hitachi, Darmstadt, Germany) applying the European standard method (DIN EN 12823-2, 2000). The contents of $\alpha_{-}, \beta_{-}, \gamma_{-}$, and $\delta$-tocopherol were determined on the same HPLC after $\mathrm{KOH}$ saponification according to Kälber et al. (2011). The FA were extracted with a solvent extractor (ASE 200, Dionex Corporation, Sunnyvale, CA) using a nonpolar/polar hexane:isopropanol mixture (3 to $2 \mathrm{vol} / \mathrm{vol}$ ). The FA were esterified to FAME using the IUPAC (1987) method 2.301. A GC (HP6890, Hewlett Packard, Palo Alto, CA) equipped with an FID detector and a CP7421 column $(200 \mathrm{~m} \times 0.25 \mathrm{~mm}, 0.25 \mu \mathrm{m}$; Varian, Darmstadt, Germany) was used to separate and quantify the FAME. The internal standard was C11:0. The ME content of spirulina (MJ $/ \mathrm{kg}$ of DM) was estimated as $0.0159 \times$ digestible $\mathrm{CP}(\mathrm{g} / \mathrm{kg}$ of $\mathrm{DM})+0.0377 \times$ digestible $\mathrm{EE}(\mathrm{g} / \mathrm{kg}$ of $\mathrm{DM})+0.0147 \times$ digestible $\mathrm{N}$-free extract (NFE, g/kg of DM; Agroscope, 2020). Coefficients of digestibility for spirulina were 0.738 for $\mathrm{CP}$, 0.625 for EE, and 0.67 for NFE as indicated by Hintz et al. (1966). Nitrogen-free extract (\%) of spirulina was calculated as $\mathrm{DM} \%-(\mathrm{Ash} \%+\mathrm{EE} \%+\mathrm{CP} \%)$. The $\mathrm{ME}$ content of the other diet components was estimated according to equations and digestibility coefficients provided by Agroscope (2020).

\section{Milk Sampling and Analysis}

In the sampling period, samples were collected at each milking and pooled per day according to milk yield. On d 1, 3, 8, 9, 15, and 18 of the sampling period, $50 \mathrm{~mL}$ of pooled milk samples conserved with 2-bromo2-nitropropane-1,3-diol (Bronopol, D\&F Inc. Dublin, CA) were subjected to compositional analysis by MIR spectrometry (MilkoScan FT6000, Foss, Hillerød, Denmark) and SCC determination (Fossomatic DC, Foss). The ECM yield $(\mathrm{kg} / \mathrm{d})$ was calculated following Agroscope $(2020)$ as milk yield $(\mathrm{kg}) \times[0.38 \times$ fat $(\%)+0.24$ $\times$ protein $(\%)+0.17 \times$ lactose $(\%)] / 3.14 \mathrm{MJ}$ of $\mathrm{NE}_{\mathrm{L}}$. The remaining milk samples were directly frozen at $-20^{\circ} \mathrm{C}$. The FA profile of the milk fat was analyzed in 1 pooled sample per animal by GC on the equipment used also for the feeds. Internal standards were C5:0, C9:0, C11:0, and C14:1. Response factors were calculated with $\mathrm{C} 6: 0, \mathrm{C} 13: 0$, and $\mathrm{C} 19: 0$ as standards. Indices for saturation (C14:0 + C16:0 + C18:0/ $\Sigma \mathrm{MUFA}+\Sigma \mathrm{PUFA}), \quad$ atherogenicity $\quad[(\mathrm{C} 12: 0+4$ 
$\times \quad \mathrm{C} 14: 0+\mathrm{C} 16: 0) /(\Sigma \mathrm{MUFA}+\Sigma \mathrm{n}-6+\Sigma \mathrm{n}-3)]$ and thrombogenicity $[(\mathrm{C} 14: 0+\mathrm{C} 16: 0+\mathrm{C} 18: 0) /(0.5 \times$ $\Sigma$ MUFA $+0.5 \times \Sigma \mathrm{n}-6+3 \times \Sigma \mathrm{n}-3+(\Sigma \mathrm{n}-6 / \Sigma \mathrm{n}-3)]$ of the milk fat were calculated as outlined by Ulbricht and Southgate (1991). The peroxidation index of the milk fat was calculated as $(\%$ dienoic $\mathrm{FA} \times 1+\%$ trienoic FA $\times 2+\%$ tetraenoic FA $\times 3+\%$ hexaenoic FA $\times 5$ ) following Nagyová et al. (2001). The contents of $\beta$-carotene and $\alpha$-tocopherol were determined by the same methods as applied for the feeds. The total antioxidant capacity in milk was measured with a commercial kit (OxiSelectTM Total Antioxidant Capacity Assay Kit, Cell Biolabs, San Diego, CA) following the manufacturer's instructions for aqueous food samples. The milk samples were defrosted overnight and diluted with acetone $(80 \%)$ to a $35 \%$ mix of milk. After vortexing, the samples were incubated for $30 \mathrm{~min}$ at ambient temperature under constant agitation and centrifuged $(14,500 \times g)$. The supernatant was analyzed. The milk color space (lightness, L*; redness, a*; yellowness, $b^{*}$ ) was measured in duplicate per sample 4 times during the sampling period using the Chroma-Meter CR-300 (Minolta, Osaka, Japan). On d 8 and 15, individual evening milk samples were stored at $4^{\circ} \mathrm{C}$ overnight and mixed with the subsequent respective morning samples proportionately to morning and evening milk yield for the determination of the milk coagulation properties. Briefly, triplicate samples of $10 \mathrm{~mL}$ of milk were incubated at $36^{\circ} \mathrm{C}$ with $100 \mu \mathrm{L}$ of $3 \%$ ( $\mathrm{vol} / \mathrm{vol}$ ) rennet solution (Pacovis Premium, $215 \mathrm{IMCU} / \mathrm{kg}$, Pacovis Amrein, Belp, Switzerland). The rennet coagulation time $(\mathbf{R C T})$, the curd firming rate $\left(\mathrm{k}_{20}\right)$, and the curd firmness 30 min after rennet addition $\left(\mathrm{a}_{30}\right)$ were measured with a Lattodinamografo (Foss).

The entire milk produced on d 9 and 10, as well as on d 16 and 17, was collected separately from each cow. Within each feeding group, milk from pairs of cows was blended. For that, cows were grouped according to their milk fat content measured on d 8 and 15 to obtain 3 replicates (Spirulina 1-6 and Control 1-6) of milk samples per experimental group with comparable milk fat content. We pooled individual milks according to fat content to mimic milk fat standardization as applied in milk industry, as visual, flavor, and texture attributes of milk are clearly influenced by milk fat content (Schiano et al., 2017). The resulting 12 milk mixtures were kept at $4^{\circ} \mathrm{C}$ (Milk\&Cheese50, FDstore, Spilamberto, Italy) until being homogenized and pasteurized (18 s at $79.5^{\circ} \mathrm{C}$ ) in a small-scaled industrial plant (Bischof Anlagenbau AG, Waldkirch, Switzerland) and stored in dark glass bottles. Milk samples were preserved at $4^{\circ} \mathrm{C}$ until the sensory evaluation sessions taking place after 4,5 , and $6 \mathrm{~d}$ of storage.
A sensory panel ( $\mathrm{n}=13$ to 17 per session) trained for milk and milk products assessed the 12 milk samples. The method of triangle test was chosen to evaluate potential sensory differences between milk of spirulina-fed and soybean-fed cows. In each triangle test, 2 out of the 3 samples were the same and one was different. The panelists were asked to identify the odd sample. Each replicate from the spirulina-fed group was tested against each replicate from the soybean meal-fed group. The resulting total of 18 triangle tests was divided into 6 test sessions, consisting of 3 triangle tests each. The tests were conducted over a period of 2 weeks. Within each week, the presentation order of the triangle tests was randomized over all sessions and panelists. Panelists evaluated samples in individual sensory booths under daylight condition. Serving temperature was $14^{\circ} \mathrm{C}$. All samples were coded with random 3-digit numbers. The results of the 3 triangle tests with 1 milk sample (Control 2) from the soybean meal-fed group were excluded because of a milk storage problem. Eventually, 15 triangular tests, 9 of which conducted by 13 panelists, 3 conducted by 14 panelists, and 3 conducted by 17 panelists, were considered.

\section{Rumen Fluid Sampling and Analysis}

Rumen fluid was sampled on d 16 of the experimental period $2 \mathrm{~h}$ after the morning milking using an oro-ruminal probe (SELEKT Pump and Collector, Nimrod Veterinary Products, Gloucestershire, UK). We drew 1.5 L rumen fluid, whereby the first $500 \mathrm{~mL}$ were discarded to avoid saliva contamination. The animals were fasted for at least $2 \mathrm{~h}$ before rumen fluid collection. The rumen fluid was immediately filtered through 4 layers of gauze. The $\mathrm{pH}$ and ammonia concentration were measured directly after collection with a potentiometer ( $\mathrm{pH}$ : model 632; ammonia: model 713; Metrohm, Herisau, Switzerland). Then $4 \mathrm{~mL}$ of rumen fluid were centrifuged $\left(4,000 \times g, 5 \mathrm{~min}, 24^{\circ} \mathrm{C}\right)$, and 2 $\mathrm{mL}$ of the supernatant were conserved at $-20^{\circ} \mathrm{C}$ until VFA analysis using HPLC (La Chrom, L-7000 series, Hitachi Ltd., Tokyo, Japan) according to Ehrlich et al. (1981). The total phenol concentration in rumen fluid was measured with the same method as that applied to the milk.

\section{Blood Sampling and Analysis}

Blood samples were drawn from the jugular vein 2 $\mathrm{h}$ after the morning milking on d 16 of the sampling period and collected into tubes containing EDTA and clot-activator for plasma and serum collection, respectively. Blood samples were centrifuged $(1,200 \times g, 10$ 
$\min , 4^{\circ} \mathrm{C}$ ) and stored at $-80^{\circ} \mathrm{C}$. Tocopherol and total phenols concentrations were analyzed in plasma using the same methods as those used for milk. Total antioxidant capacity was measured in serum using the OxiSelectTM Total Antioxidant Capacity Assay Kit (Cell Biolabs, San Diego, CA) according to the manufacturer's instructions.

\section{Calculations and Statistical Analysis}

The apparent transfer efficiency of FA from diets to milk was calculated by dividing the daily secretion of a certain FA $(\mathrm{g} / \mathrm{d})$ by the daily intake $(\mathrm{g} / \mathrm{d})$ of the same FA. The daily secretion of a certain FA in milk was calculated as the milk fat yield $(\mathrm{g} / \mathrm{d}) \times 0.94 \times$ proportion of FA in milk (\% of FA), where the constant 0.94 is the average proportion of FA in milk fat as reported by Halmemies-Beauchet-Filleau et al. (2014). Data were analyzed with the MIXED procedure of SAS version 9.4 (SAS Institute, Cary, NC). The statistical model was as follows:

$$
\mathrm{Y}_{\mathrm{ijk}}=\mu+\mathrm{D}_{\mathrm{i}}+\mathrm{B}_{\mathrm{j}}+\mathrm{D}_{\mathrm{i}} \times \mathrm{B}_{\mathrm{j}}+\varepsilon_{\mathrm{ijk}},
$$

where $Y_{\mathrm{ijk}}$ represents the dependent variable, $\mu$ the overall mean, $D_{i}$ the effect of the diet, $B_{j}$ the effect of the breed, $\mathrm{D}_{\mathrm{i}} \times \mathrm{B}_{\mathrm{j}}$ the diet and breed interaction, and $\varepsilon_{\mathrm{ijk}}$ represents the random residual error. Individual cow served as experimental unit. For milk and ECM yield, data from the week before the experiment were used as covariates in the model. For milk composition (fat, protein and lactose content) and SCC, data from the sampling before the start of the experiment were included as covariates in the model. Differences between least squares means were tested with $t$-test. Significance was set to $P<0.05$. Tendency was considered at $0.05 \leq P<0.1$. The data are presented as least squares means and standard error of the mean. The SCC were log-transformed before statistical analysis and determination of the $P$-value. Arithmetic means are reported in the table in parentheses below the logtransformed values. Significance of each triangle test at a 95\% 2-sided confidence interval according to the exact binomial distribution was calculated with the function discrim of the package sensR (Christensen and Brockhoff, 2020) in R (R Core Team, Vienna, Austria).

\section{RESULTS}

\section{Experimental Diets and Feed Intake}

Spirulina contained $20.1 \%$ more CP than the soybean meal (Table 1). It had a 5-fold higher EE content com- pared with the soybean meal (6.04 vs. $1.14 \%$ of DM). Spirulina was rich in tocopherols, with $\alpha$-tocopherol being most abundant, followed by $\beta$-tocopherol, $\gamma$-tocopherol, and $\delta$-tocopherol. Furthermore, spirulina contained a substantial amount of $\beta$-carotene and some phenolic compounds, $90 \%$ of which were nontannin phenols and $10 \%$ hydrolyzable tannins. The most abundant FA in spirulina were C16:0, GLA, C18:2n-6 (linoleic acid, LA) and C16:1n-7 (Table 2). Consequently, the spirulina diet contained 60 times more GLA and more than 2 times more $\mathrm{C} 16: 1 \mathrm{n}-7$ than the soybean meal diet. Although present only in small amounts, C14:1, C16:2, C16:4, cis-13 C18:1, and C20:3n-6 were detected solely in the spirulina-supplemented diet. Spirulina contained only small amounts of C20:5n-3 (eicosapentaenoic acid, EPA).

\section{Intake, Performance, and Milk Characteristics}

The DMI was not affected by the dietary treatment (Table 3). The average BW of the animals did not differ between the groups as was also the case for milk yield and ECM yield. No effect of the dietary treatment was observed on contents of fat, protein, lactose, urea and SCC in milk (Table 3). The $\beta$-carotene concentration was higher $(P<0.01)$ in total milk and in milk fat of spirulina-fed cows $(4.36$ vs. $2.59 \mu \mathrm{g} / \mathrm{g}$ of fat in the soybean meal group). The concentrations of $\alpha$-tocopherol and total phenols as well as the total antioxidant capacity did not differ between the 2 groups. The milk from the spirulina-fed cows had a higher $(P<0.05)$ yellowness $\left(+1.1\right.$ in $\left.b^{*}\right)$ at unchanged lightness and redness. Rennet coagulation time, curd firming rate, and curd firmness $30 \mathrm{~min}$ after rennet addition were not affected by the diet.

Among the SFA, the proportions of C17:0 and C20:0 were higher $(P<0.01)$ by 118 and $28 \mathrm{mg} / 100 \mathrm{~g}$ of FAME, respectively, in the milk from spirulina-fed cows compared with the milk from control animals (Table 4 and Table A1). However, the total SFA proportion was not affected by the substitution of soybean meal by spirulina in the diet (Table 5). The substitution of soybean meal by spirulina resulted in a lower $(P<$ $0.01)$ cis-9 $\mathrm{C} 16: 1$ proportion in milk fat $(-0.49 \mathrm{~g} / 100$ $\mathrm{g}$ of FAME; Table 4). The proportions of trans-11 C18:1 (vaccenic acid, VA; $+0.31 \mathrm{mg} / 100 \mathrm{~g}$ of FA), trans $-6+7+8 \mathrm{C} 18: 1(+21 \mathrm{mg} / 100 \mathrm{~g}$ of $\mathrm{FA})$, and cis-11 C20:1 $(+13 \mathrm{mg} / 100 \mathrm{~g}$ of FA) were higher $(P<0.05)$ in milk fat from spirulina-fed cows. Consequently, the sum of the C18:1 trans isomers was higher $(+0.4 \mathrm{~g} / 100$ $\mathrm{g}$ of FA) in milk fat from spirulina-fed cows (Table 5). The proportion of trans-9,trans-11 C18:2 was lower $(P$ $<0.05)$ in milk from spirulina-fed cows $(-13 \mathrm{mg} / 100 \mathrm{~g}$ 
Table 1. Proximate nutrient composition in DM and contents of extractable phenols, $\beta$-carotene, and tocopherols of the individual feeds and the experimental diets ( $\mathrm{n}=2$ for individual feeds, $\mathrm{n}=3$ for complete diets)

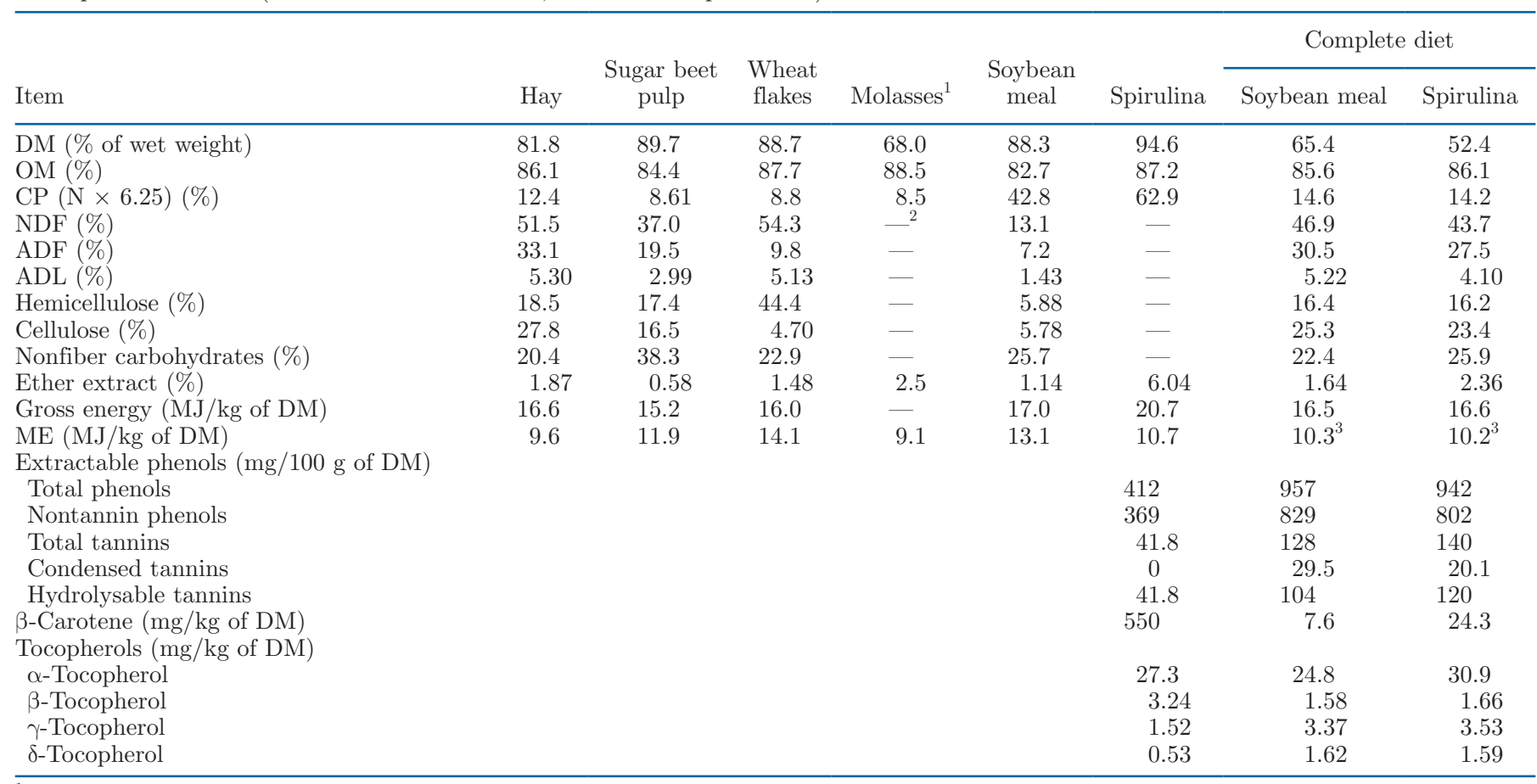

${ }^{1}$ According to specifications by the supplier.

${ }^{2}$ Not analyzed.

${ }^{3}$ Calculated based on the ME content of the ingredients derived from standard equations of Agroscope (2020).

of FAME) (Table 4). On the contrary, the proportions of trans-9,trans-12 C18:2 (+10 mg/100 g of FAME) and GLA $(+19 \mathrm{mg} / 100 \mathrm{~g}$ of FAME $)$ were higher $(P<$ 0.05 and $P<0.01$, respectively) in milk from spirulinafed cows. Despite the differences observed for some individual MUFA and PUFA, the total proportions of MUFA and PUFA in milk fat were not affected by the dietary treatment (Table 5). Furthermore, the total CLA content in milk was not changed by the substitution of soybean meal by spirulina. Likewise, the saturation, peroxidation, atherogenicity and thrombogenicity indices of the milk fat were not affected by the diet. The apparent transfer efficiency of total n- 6 FA was lower in the spirulina-supplemented diet, whereas the apparent transfer efficiencies of total n-3 FA, LA and $\alpha$-linolenic acid (ALA) were not affected by the diet.

The average fat and protein contents of the milk samples $(\mathrm{n}=6)$ from the spirulina-fed group used for the sensory analysis were $4.6 \pm 0.15 \%$ and $3.7 \pm 0.04 \%$, respectively, whereas the milk $(\mathrm{n}=6)$ from the control group contained $5.2 \pm 0.09 \%$ fat and $4.1 \pm 0.12 \%$ protein. In total, only 3 out of the 15 triangle tests were significant $(P<0.01)$ with $76.9 \%, 69.2 \%$ and $69.2 \%$ correct answers (Table 6 ).

\section{Rumen Fluid Characteristics and Indicators in Blood}

At unchanged $\mathrm{pH}$ and ammonia concentration, the rumen fluid of spirulina-fed cows had a lower $(P<$ $0.05)$ concentration of total VFA $(-26 \%)$ than that of the soybean meal-fed cows (Table 7). However, the molar proportions of acetate, propionate, isobutyrate, isovalerate and valerate in the rumen fluid were not affected by the dietary treatment. The concentration of total phenols in the rumen fluid did not differ between the 2 dietary treatments. Plasma total phenol and $\alpha$-tocopherol concentrations as well as serum total antioxidant capacity did not differ between the 2 treatments.

\section{DISCUSSION}

\section{Spirulina Characteristics and Its Effects on Performance}

Spirulina is clearly richer in CP than soybean meal, even when applying the spirulina-specific nitrogen-toCP conversion factor of 5.95 as proposed by González López et al. (2010), resulting in only $59.9 \%$ instead of 
$62.9 \% \mathrm{CP}$ in $\mathrm{DM}$. These values are in the range of the $\mathrm{CP}$ contents reported for other spirulina products (Lamminen et al., 2017; Wild et al., 2018). The EE content of $6.0 \%$ in the batch of spirulina tested was relatively low compared with other commercially available microalgae such as Chlorella sp. and Nannochloropsis sp., but was comparable to values presented for spirulina in previous literature (Madeira et al., 2017; Wild et al., 2018). In contrast to some previous reports (reviewed by Madeira et al., 2017), in the batch of spirulina used in the present study, no very long-chain

Table 2. Mean fatty acid (FA) composition (mg/100 g of DM) of the Spirulina powder and of the 2 complete diets ${ }^{1}$

\begin{tabular}{|c|c|c|c|}
\hline \multirow[b]{2}{*}{ Item } & \multirow[b]{2}{*}{$\begin{array}{l}\text { Spirulina } \\
(\mathrm{n}=2)\end{array}$} & \multicolumn{2}{|c|}{ Complete diet } \\
\hline & & $\begin{array}{l}\text { Soybean meal } \\
\quad(\mathrm{n}=3)\end{array}$ & $\begin{array}{c}\text { Spirulina } \\
(\mathrm{n}=3)\end{array}$ \\
\hline Total FA ( $\%$ of DM) & 4.05 & 1.42 & 1.56 \\
\hline C8:0 & 4.34 & 0.47 & 0.36 \\
\hline C10:0 & 1.92 & 0.44 & 0.46 \\
\hline C12:0 & 0.63 & 4.21 & 3.99 \\
\hline C14:0 & 3.99 & 7.59 & 7.78 \\
\hline C15:0 & 1.01 & 3.12 & 3.22 \\
\hline C16:0 & 1,763 & 265 & 346 \\
\hline iso-C16:0 & 63.8 & 20.6 & 21.7 \\
\hline anteiso-C16:0 & 1.83 & ND & ND \\
\hline C17:0 & 4.79 & 3.43 & 3.65 \\
\hline C18:0 & 41.4 & 33.3 & 33.3 \\
\hline C20:0 & 2.04 & 8.50 & 7.61 \\
\hline $\mathrm{C} 21: 0$ & 10.8 & 0.92 & 1.35 \\
\hline C22:0 & ND & 12.2 & 11.6 \\
\hline $\mathrm{C} 23: 0$ & ND & 1.24 & 1.06 \\
\hline C24:0 & ND & 10.8 & 10.1 \\
\hline $\mathrm{C} 12: 1$ & 5.21 & 2.06 & 2.08 \\
\hline C14:1 & 1.91 & ND & 0.210 \\
\hline C15:1 & 4.36 & ND & ND \\
\hline C16:1n-7 & 135 & 3.7 & 10.4 \\
\hline C17:1 & ND & 0.98 & 0.84 \\
\hline C18:1n-9 & 65.9 & 70.9 & 66.3 \\
\hline cis-11-C18:1 & 11.9 & 7.8 & 7.3 \\
\hline cis-13-C18:1 & 7.96 & ND & 0.69 \\
\hline $\mathrm{C} 20: 1 \mathrm{n}-7$ & 1.74 & 1.66 & 1.55 \\
\hline C20:1n-9 & 1.32 & 0.88 & 0.78 \\
\hline $\mathrm{C} 22: 1$ & ND & 0.57 & 0.51 \\
\hline C24:1n-9 & ND & 0.68 & 0.71 \\
\hline C16:2 & 12.7 & ND & 0.85 \\
\hline C18:2n-6 (LA) & 746 & 291 & 306 \\
\hline $\mathrm{C} 20: 2$ & 2.09 & 1.29 & 1.30 \\
\hline $\mathrm{C} 22: 2$ & ND & 4.33 & 3.46 \\
\hline C18:3n-3 & 2.63 & 661 & 649 \\
\hline C18:3n-6 (GLA) & 1,123 & 0.8 & 50.4 \\
\hline C20:3n-3 & ND & 1.03 & 1.00 \\
\hline C20:3n-6 & 14.1 & ND & 0.711 \\
\hline C16:4 & 8.02 & ND & 0.95 \\
\hline C20:5n-3 (EPA) & 2.74 & 0.75 & 0.76 \\
\hline$\Sigma \mathrm{SFA}$ & 1,834 & 372 & 452 \\
\hline$\Sigma$ MUFA & 236 & 89 & 91 \\
\hline$\Sigma$ PUFA & 1,904 & 961 & 1,015 \\
\hline$\Sigma$ n-3 fatty acids & 5.37 & 663 & 651 \\
\hline$\Sigma$ n-6 fatty acids & 1,884 & 292 & 358 \\
\hline n-6:n-3 fatty acid ratio & 351 & 0.44 & 0.55 \\
\hline
\end{tabular}

${ }^{1} \mathrm{ND}=$ not detected; EPA $=$ eicosapentaenoic acid; GLA $=\gamma$-linolenic acid; LA = linoleic acid.
( $>21$ carbons) FA could be detected. Variability in the FA profile of spirulina can be explained by production conditions (temperature, light, $\mathrm{pH}$, nutrient availability), strain diversity (Ötleş and Pire, 2001; Wild et al., 2018), and from the solvent used for FA analysis, as the solubility of different lipid fractions of spirulina may vary (Pohndorf et al., 2016).

The DM intake did not differ between the experimental groups. Therefore, we assume that the palatability of the diet was not reduced by the inclusion of $5 \%$ spirulina. In contrast to our results, Lamminen et al. (2019b) found a reduction in DM intake by up to $3.5 \%$ in cows fed with $2.6 \%$ spirulina included in grass silagebased diets, partially substituting either rapeseed meal or fava beans. As in the present study, spirulina was included in the complete diet and the animals were not able to select or ingest higher forage proportions in the experiment of Lamminen et al. (2019b). In our experiment, we added liquid molasses to both experimental diets, which might have enhanced the acceptability and improved the palatability of the spirulina-supplemented diet resulting in similar total intake levels as in the soybean meal-fed group. Indeed, the addition of liquid molasses to TMR diets was reported to increase DMI and decrease feed sorting (DeVries and Gill, 2012). The conditions under which palatability is impaired by the addition of spirulina remains unclear because dosage, type of substituted protein feed, and feeding system seem to interact. However, the inclusion of molasses might be a convenient strategy to increase the palatability of microalgae supplemented diets.

\section{Effects of Spirulina on Ruminal Fermentation}

The specific composition of spirulina may also affect rumen microbes and thus ruminal fermentation of nutrients. The lower VFA concentration in rumen fluid found in the spirulina-fed group is consistent with the low in vitro ruminal fermentation reported by Wild et al. (2019) for spirulina. Indeed, the higher CP content $(+20.1 \%$ compared with soybean meal $)$ and consequently lower carbohydrate proportion in spirulina compared with soybean meal might limit the availability of energy substrates in the rumen. Rumen microbes mainly rely on dietary polysaccharides such as starch, cellulose, hemicellulose, and pectin as energy source. The polysaccharide content of spirulina was reported to be approximately 13\% of DM (Kurd and Samavati, 2015), whereas the highly digestible nonfiber carbohydrates accounted for $26 \%$ of the DM in soybean meal. Furthermore, the decreased ruminal fermentation does not seem to be related to the higher EE intake from the spirulina-supplemented diet as no negative effects on ruminal fermentation and digestibility are 
expected with up to $8 \%$ dietary fat intake (Palmquist and Conrad, 1978).

We observed an accumulation of rumen biohydrogenation intermediates, such as trans-6+7+8 C18:1 and $\mathrm{VA}$, in the milk fat of spirulina-fed cows compared with the soybean meal-fed cows. This might indicate the occurrence of an incomplete biohydrogenation of the microalgal PUFA in the rumen. Consistent with these findings, Boeckaert et al. (2008) found an accumulation of $\mathrm{C} 18: 1$ trans $\mathrm{FA}$ in the rumen after dietary algae supplementation (Schizochytrium sp.), which was associated with changes in the presence and activity of Butyrivibrio sp. in the rumen. The assumption of a partial inhibition of the ruminal biohydrogenation by algal constituents is further supported by the higher proportions of other precursors of the terminal FA, C18:0, in the process of the rumen biohydrogenation such as cis-9,trans-11 C18:2 (rumenic acid, RA) and trans-9,trans-12 C18:2, which were both accordingly higher in the milk fat from spirulina-fed cows. The similar proportion of C18:0 in milk fat of control and spirulina-fed cows provides further support that the higher proportion of trans- $6+7+8 \mathrm{C} 18: 1$ and VA resulted from the partially inhibited biohydrogenation and was not the result of a higher EE intake.

\section{Effects of Spirulina on Further Fatty Acids in Milk Fat}

Generally, the milk FA profile of the spirulina-fed cows was rather similar to that of the cows fed the control diet. The average proportions ( $\mathrm{g} / 100 \mathrm{~g}$ of FAME) of SFA (71.6), MUFA (24.3) and PUFA (4.1) were similar to those previously reported for hay-based diets (Coppa et al., 2011). In contrast, Póti et al. (2015) reported more MUFA in the milk fat of spirulina-supplemented cows ( $0.7 \%$ of DM intake) compared with cows fed a diet with soybean meal, whereby both diets were based on alfalfa hay, corn silage and concentrate $(38 \%, 47 \%$, and $15 \%$ of DM, respectively). The GLA is a characteristic FA for spirulina. In fact, spirulina contained $1.1 \%$ of DM of GLA, which is consistent with previous reports (reviewed by Madeira et al., 2017). A small part of the very high proportion found in the diet was recovered in the milk fat and thus escaped the ruminal biohydrogenation. In human nutrition, GLA is considered hypocholesterolemic (Sugano et al., 1986) and its presence in milk and dairy products is considered to be desirable. Moreover, GLA functions as a precursor of series- 1 prostaglandins with anti-inflammatory properties and plays an important role in fertility (Abayasekara and Wathes, 1999). However, the observed limited increase might be

Table 3. Effect of spirulina supplementation on feed intake, performance, and milk composition $(\mathrm{n}=6)$

\begin{tabular}{|c|c|c|c|c|}
\hline \multirow[b]{2}{*}{ Item } & \multicolumn{2}{|c|}{ Diet } & \multirow[b]{2}{*}{ SEM } & \multirow[b]{2}{*}{$P$-value } \\
\hline & Soybean meal & Spirulina & & \\
\hline \multicolumn{5}{|l|}{ Intake and performance } \\
\hline Total DM $(\mathrm{kg})$ & 17.2 & 17.6 & 0.90 & 0.765 \\
\hline Milk yield (kg/d) & 16.7 & 18.1 & 0.79 & 0.238 \\
\hline ECM yield $(\mathrm{kg} / \mathrm{d})$ & 19.0 & 20.3 & 0.93 & 0.344 \\
\hline ECM/DMI $(\mathrm{kg} / \mathrm{kg})$ & 1.11 & 1.16 & 0.075 & 0.618 \\
\hline BW (kg) & 718 & 691 & 40.4 & 0.641 \\
\hline \multicolumn{5}{|l|}{ Milk gross constituents (\%) } \\
\hline Fat & 4.95 & 4.72 & 0.117 & 0.210 \\
\hline Protein & 3.96 & 4.02 & 0.045 & 0.437 \\
\hline Casein & 3.20 & 2.96 & 0.099 & 0.126 \\
\hline Lactose & 4.63 & 4.50 & 0.059 & 0.141 \\
\hline Urea, mg/dL & 26.6 & 27.3 & 1.16 & 0.680 \\
\hline $\mathrm{SCC}^{1}(\times 1,000 / \mathrm{mL})$ & $4.69(118)$ & $4.82(135)$ & 0.139 & 0.568 \\
\hline \multicolumn{5}{|l|}{ Milk minor constituents (per L) } \\
\hline$\beta$-Carotene $(\mu \mathrm{g})$ & 135 & 207 & 17.4 & 0.019 \\
\hline$\alpha$-Tocopherol ( $\mu \mathrm{g})$ & 613 & 607 & 57.7 & 0.946 \\
\hline Total phenols (mg) & 19.4 & 19.3 & 1.20 & 0.929 \\
\hline Total antioxidant capacity $\left(\mathrm{m} M \mathrm{UA}_{\mathrm{Eq}}^{2}\right)$ & 0.066 & 0.063 & 0.004 & 0.662 \\
\hline \multicolumn{5}{|l|}{ Milk color } \\
\hline Lightness (L* index) & 75.1 & 75.1 & 0.175 & 0.954 \\
\hline Redness $\left(a^{*}\right.$ index $)$ & -5.65 & -5.65 & 0.073 & 0.973 \\
\hline Yellowness (b* index $)$ & 13.8 & 14.9 & 0.241 & 0.013 \\
\hline \multicolumn{5}{|l|}{ Milk coagulation properties } \\
\hline Rennet coagulation time (RCT, min) & 9.11 & 9.40 & 0.616 & 0.748 \\
\hline Curd firming rate $\left(\mathrm{k}_{20}, \mathrm{~min}\right)$ & 1.27 & 1.23 & 0.100 & 0.768 \\
\hline Curd firmness $\left(\mathrm{a}_{30}, \mathrm{~mm}\right.$ after $\left.30 \mathrm{~min}\right)$ & 48.1 & 40.4 & 4.18 & 0.233 \\
\hline
\end{tabular}

${ }^{1}$ Least squares means of natural log-transformed SCC. Arithmetic means are presented in parentheses next to the log-transformed values.

${ }^{2} \mathrm{UA}_{\mathrm{Eq}}=$ uric acid equivalents. 
too small to be nutritionally relevant in terms of GLA supply to consumers via milk and dairy products. With regard to other indicators of nutritional quality for human health, no particular benefits resulted from the supplementation of the dairy cows with spirulina. The atherogenicity and thrombogenicity indices of the milk fat, as defined by Ulbricht and Southgate (1991), were not affected by the dietary treatments. Whether or not trans FA from dairy foods are harmful with regard to coronary heart diseases (German et al., 2009) is still controversially discussed (de Souza et al., 2015), and thus the nutritional effect of the increased content of C18:1 trans $\mathrm{FA}$ in milk from spirulina-fed cows cannot be evaluated with certainty. However, a considerable part of this increase occurred through the milk-specific trans-11 isomer of C18:1 (VA), which is regarded to be beneficial for human health, and is related to RA, which is regarded as similarly beneficial (Belury, 2002).

Table 4. Effect of spirulina supplementation on fatty acids in milk fat (\% of total FAME) $(\mathrm{n}=6)$

\begin{tabular}{|c|c|c|c|c|}
\hline \multirow[b]{2}{*}{ Item $^{1}$} & \multicolumn{2}{|c|}{ Diet } & \multirow[b]{2}{*}{ SEM } & \multirow[b]{2}{*}{$P$-value } \\
\hline & Soybean meal & Spirulina & & \\
\hline Fatty acids $<\mathrm{C} 16^{2}$ & 29.6 & 29.0 & 0.82 & 0.604 \\
\hline $\mathrm{C} 16: 0$ & 38.1 & 37.3 & 1.73 & 0.747 \\
\hline $\mathrm{C} 16: 0$ iso & 0.191 & 0.246 & 0.0198 & 0.100 \\
\hline C16:0 anteiso & 0.056 & 0.052 & 0.0066 & 0.672 \\
\hline $\mathrm{C} 17: 0$ & 0.704 & 0.822 & 0.0193 & 0.005 \\
\hline $\mathrm{C} 17: 0$ iso & 0.027 & 0.032 & 0.0024 & 0.189 \\
\hline C17:0 anteiso & 0.071 & 0.065 & 0.0022 & 0.129 \\
\hline C18:0 & 5.79 & 6.29 & 0.287 & 0.268 \\
\hline C20:0 & 0.085 & 0.113 & 0.0041 & 0.003 \\
\hline $\mathrm{C} 22: 0$ & 0.051 & 0.057 & 0.0018 & 0.063 \\
\hline cis-9 C16:1 & 2.21 & 1.72 & 0.069 & 0.002 \\
\hline trans-9 C16:1 & 0.593 & 0.623 & 0.0310 & 0.527 \\
\hline cis-9 C17:1 & 0.319 & 0.323 & 0.0156 & 0.849 \\
\hline C18:1n-9 & 15.4 & 16.1 & 0.780 & 0.551 \\
\hline trans $-6+7+8 \mathrm{C} 18: 1$ & 0.105 & 0.126 & 0.0059 & 0.049 \\
\hline trans-9 C18:1 & 0.135 & 0.150 & 0.0068 & 0.174 \\
\hline trans-10 C18:1 & 0.139 & 0.163 & 0.0083 & 0.087 \\
\hline trans-11 C18:1 (VA) & 1.19 & 1.49 & 0.057 & 0.009 \\
\hline trans-12 C18:1 & 0.185 & 0.217 & 0.0113 & 0.085 \\
\hline cis-10 C18:1 & 0.117 & 0.129 & 0.0068 & 0.280 \\
\hline cis-11 C18:1 & 0.419 & 0.450 & 0.0279 & 0.463 \\
\hline cis-12 C18:1 & 0.103 & 0.103 & 0.0068 & 0.957 \\
\hline cis-13 C18:1 & 0.076 & 0.079 & 0.0081 & 0.806 \\
\hline cis-14+trans-16 C18:1 & 0.162 & 0.177 & 0.0086 & 0.265 \\
\hline cis-5 C20:1 & 0.025 & 0.027 & 0.0023 & 0.640 \\
\hline cis-9 C20:1 & 0.115 & 0.120 & 0.0079 & 0.634 \\
\hline cis-11 C20:1 & 0.037 & 0.050 & 0.0038 & 0.050 \\
\hline cis-9 C22:1 & 0.007 & 0.007 & 0.0003 & 0.236 \\
\hline C18:2n-6 (LA) & 1.28 & 1.21 & 0.061 & 0.445 \\
\hline cis-9,cis-11 C18:2 & 0.040 & 0.044 & 0.0033 & 0.396 \\
\hline cis-9,cis-15 C18:2 & 0.035 & 0.033 & 0.0026 & 0.524 \\
\hline cis-9,trans-11 C18:2 (RA) & 0.612 & 0.685 & 0.0558 & 0.389 \\
\hline cis-9,trans-12 C18:2 & 0.061 & 0.064 & 0.0064 & 0.771 \\
\hline cis-9,trans-13+trans-8,cis-12 C18:2 & 0.139 & 0.142 & 0.0098 & 0.793 \\
\hline trans-9,trans-11 C18:2 & 0.041 & 0.028 & 0.0034 & 0.035 \\
\hline trans-9,trans-12 C18:2 & 0.060 & 0.070 & 0.0020 & 0.012 \\
\hline trans-11,cis-15+trans-9,cis-12 C18:2 & 0.371 & 0.429 & 0.0207 & 0.097 \\
\hline C18:3n-3 & 0.877 & 0.835 & 0.0281 & 0.336 \\
\hline C18:3n-6 (GLA) & 0.038 & 0.057 & 0.0043 & 0.020 \\
\hline $\mathrm{C} 20: 2 \mathrm{n}-6$ & 0.035 & 0.039 & 0.0016 & 0.145 \\
\hline C20:3n-6 & 0.081 & 0.083 & 0.0107 & 0.917 \\
\hline C20:4n-6 & 0.099 & 0.100 & 0.0080 & 0.909 \\
\hline$C 20: 3 n-3$ & 0.013 & 0.013 & 0.0009 & 0.922 \\
\hline C20:4n-3 & 0.006 & 0.006 & 0.0006 & 0.877 \\
\hline C22:4n-6 & 0.051 & 0.057 & 0.0026 & 0.133 \\
\hline C20:5n-3 (EPA) & 0.064 & 0.057 & 0.0045 & 0.308 \\
\hline $\mathrm{C} 22: 5 \mathrm{n}-3$ & 0.073 & 0.070 & 0.0050 & 0.712 \\
\hline C22:6n-3 (DHA) & 0.009 & 0.009 & 0.0006 & 0.323 \\
\hline
\end{tabular}

${ }^{1} \mathrm{VA}=$ vaccenic acid; EPA = eicosapentaenoic acid; DHA = docosahexaenoic acid; GLA = $\gamma$-linolenic acid; LA $=$ linoleic acid; $\mathrm{RA}=$ rumenic acid

${ }^{2}$ Individual short- and medium-chain fatty acids are presented in Appendix Table A1. 
Table 5. Effect of spirulina supplementation on groups and ratios of selected fatty acids (\% of total FAME) in milk and estimated transfer efficiency from feed to milk of selected UFA and their sums $(n=6)$

\begin{tabular}{lcccc}
\hline & \multicolumn{2}{c}{ Diet } & & \\
\cline { 2 - 3 } Item & Soybean meal & Spirulina & SEM & P-value \\
\hline$\Sigma$ SFA & 72.0 & 71.6 & 1.22 & 0.796 \\
$\Sigma$ MUFA & 24.0 & 24.4 & 1.05 & 0.779 \\
$\Sigma$ PUFA & 3.98 & 4.03 & 0.189 & 0.866 \\
$\Sigma$ Total n-3 fatty acids & 1.04 & 0.99 & 0.036 & 0.365 \\
$\Sigma$ Total n-6 fatty acids & 1.64 & 1.61 & 0.082 & 0.815 \\
$\Sigma$ CLA isomers & 0.69 & 0.76 & 0.058 & 0.462 \\
$\Sigma$ Odd- and branched-chain fatty acids & 4.52 & 5.03 & 0.203 & 0.127 \\
$\Sigma$ C10 to C15 & 26.2 & 25.8 & 0.88 & 0.765 \\
$\Sigma$ trans C18:1 isomers & 1.75 & 2.15 & 0.081 & 0.013 \\
$\Sigma$ cis C18:1 isomers & 16.1 & 16.9 & 0.82 & 0.547 \\
Ratios & & & & \\
n-6/n-3 fatty acids & 1.57 & 1.63 & 0.037 & 0.339 \\
cis-9 C18:1/C16:0 & 0.414 & 0.436 & 0.0392 & 0.704 \\
Indices & & & & \\
Saturation index & 2.06 & 2.01 & 0.139 & 0.808 \\
Atherogenicity index & 3.58 & 3.52 & 0.182 & 0.823 \\
Thrombogenicity index & 3.47 & 3.44 & 0.220 & 0.937 \\
Peroxidation index & 5.75 & 5.76 & 0.270 & 0.966 \\
Apparent transfer efficiency of fatty acids ${ }^{2}$ & & & & \\
C18:2n-6 (LA) & 0.199 & 0.176 & 0.0114 & 0.193 \\
C18:3n-3 (ALA) & 0.060 & 0.058 & 0.0029 & 0.668 \\
$\Sigma$ Total n-3 fatty acids & 0.070 & 0.069 & 0.0033 & 0.738 \\
$\Sigma$ Total n-6 fatty acids & 0.253 & 0.201 & 0.0119 & 0.015 \\
\hline
\end{tabular}

${ }^{1}$ Saturation index, atherogenicity index, and thrombogenicity index were calculated according to Ulbricht and Southgate (1991). Peroxidation index was calculated according to Nagyová et al. (2001).

${ }^{2} \mathrm{LA}=$ linoleic acid; $\mathrm{ALA}=\alpha$-linolenic acid.

Interestingly, the proportion of RA did not significantly increase with the inclusion of spirulina in the diet. Other microalgae such as Schizochytrium sp. and its DHA-enriched forms or Nannochloropsis sp. seem to be better suited for the beneficial modulation of the milk FA profile (Papadopoulos et al., 2002; Till et al., 2019; Lamminen et al., 2019a) than spirulina. The observed

Table 6. Sensory analysis (triangle test) performed on homogenized and pasteurized milk samples from spirulina-fed cows (Spirulina 1-6) and soybean meal-fed cows (Control 1-5)

\begin{tabular}{lcc}
\hline Treatment comparison & No. of correct answers & $P$-value \\
\hline Spirulina 1 vs. Control 1 & $7 / 17$ & 0.359 \\
Spirulina 2 vs. Control 1 & $7 / 17$ & 0.359 \\
Spirulina 3 vs. Control 1 & $6 / 17$ & 0.558 \\
Spirulina 1 vs. Control 3 & $6 / 14$ & 0.340 \\
Spirulina 2 vs. Control 3 & $7 / 14$ & 0.170 \\
Spirulina 3 vs. Control 3 & $6 / 14$ & 0.340 \\
Spirulina 4 vs. Control 4 & $9 / 13$ & 0.011 \\
Spirulina 5 vs. Control 4 & $3 / 13$ & 0.877 \\
Spirulina 6 vs. Control 4 & $5 / 13$ & 0.479 \\
Spirulina 4 vs. Control 5 & $7 / 13$ & 0.119 \\
Spirulina 5 vs. Control 5 & $3 / 13$ & 0.877 \\
Spirulina 6 vs. Control 5 & $9 / 13$ & 0.011 \\
Spirulina 4 vs. Control 6 & $7 / 13$ & 0.118 \\
Spirulina 5 vs. Control 6 & $10 / 13$ & 0.002 \\
Spirulina 6 vs. Control 6 & $6 / 13$ & 0.267 \\
\hline
\end{tabular}

${ }^{1}$ Indicates the number of panelists correctly selecting the odd sample against the total number of panelists that performed the test. lower apparent transfer efficiency of total n-6 FA from the spirulina diet contrasts previous results observed with spirulina (Lamminen et al., 2019a), but indicates that ruminal biohydrogenation or bioavailability of the n-6 FA in the duodenum might differ between microalgae and conventional feedstuffs such as soybean meal.

\section{Effects of Spirulina on Constituents with and Indicators of Antioxidant Properties}

The higher $\beta$-carotene concentration found in the milk of spirulina-fed cows can be directly related to the higher dietary intake of $\beta$-carotene. However, the extent of the observed increase in the milk was lower than could have been expected from the difference in the diet. The supply of $\beta$-carotene with the spirulina $\operatorname{diet}(0.4 \mathrm{~g} / \mathrm{d})$ corresponded to twice the minimal daily supply of $\beta$-carotene $(0.2 \mathrm{~g} / \mathrm{d})$ recommended by the Swiss feeding recommendations for cows in the transition period (Agroscope, 2020). Calderón et al. (2007) reported that in high-carotenoid diets, the secretion of $\beta$-carotene with the milk is limited by mechanisms regulating the transfer of $\beta$-carotene from plasma to milk, which in turn limit the proportion of $\beta$-carotene in milk fat. In addition, the absorption of $\beta$-carotene in the intestine is directly dependent on the concomitant presence of lipids in the diet (Graulet et al., 2019). The 
observed proportion of $4.36 \mu \mathrm{g}$ of $\beta$-carotene/g of milk fat was similar to the proportion $(4.21 \mu \mathrm{g} / \mathrm{g}$ of milk fat $)$ reported by Calderón et al. (2007) with a higher intake of 1.1 to $1.6 \mathrm{~g} / \mathrm{d}$ of $\beta$-carotene from grass silage and alfalfa protein concentrate. This might indicate that the milk fat was almost saturated with $\beta$-carotene or that the maximal uptake capacity of $\beta$-carotene by the mammary gland was reached (Calderón et al., 2007). Nevertheless, the supply of the cows with $\beta$-carotene through spirulina, especially around parturition, can be considered favorable, as this compound is helpful to support uterine involution and the resumption of the estrous cycle postpartum (Michal et al., 1994; Kawashima et al., 2010; Kaewlamun et al., 2011). It also would increase the $\beta$-carotene supply to the calves via the colostrum (Kaewlamun et al., 2011). Furthermore, $\beta$-carotene is an important precursor for retinol (vitamin A), and its supply is important during the entire lactation and the transition period.

Despite the higher intake of total tocopherols and ether extract in the spirulina-fed group, no differences were observed in the $\alpha$-tocopherol concentrations in blood plasma and milk. The concentrations of $\alpha$-tocopherol found in milk fat $(13.0 \pm 1.14 \mu \mathrm{g} / \mathrm{g}$ of fat) and blood plasma $(13.0 \pm 0.246 \mu \mathrm{g} / \mathrm{mL})$ were consistent with previous observations of Calderón et al. (2007). The lack of a difference in the $\alpha$-tocopherol plasma levels might indicate a lower bioavailability of $\alpha$-tocopherol from the spirulina-supplemented diet than from the soybean meal-supplemented diet. Also, the total antioxidant capacity as well as the total phenols in plasma did not differ between the 2 treatments. This may be related to the similar intake of total extractable phenols from the 2 complete diets due to the relatively low proportion of total extractable phenols found in spirulina. Consistent with this and with the unaffected plasma antioxidant capacity, also the milk antioxidant capacity did not differ between the 2 diets.

\section{Effects of Spirulina on Sensory and Processing Properties of the Milk}

The higher yellowness of the milk from the spirulinafed cows could have been related to the higher milk $\beta$-carotene content (Nozière et al., 2006). However, carotenes such as $\beta$-carotene are not the major carotenoids in spirulina, in which $83 \%$ of the total carotenoids are made up of xanthophylls (myxoxanthophyll, zeaxanthin, lutein, $\beta$-cryptoxanthin) (Anderson et al., 1991). Xanthophylls are also transferred to bovine milk (Nozière et al., 2006) and may thus have contributed to the yellow milk color. However, the only milk carotenoid we analyzed in the present study was $\beta$-carotene, which represents the main circulating carotenoid in bovine plasma and by far the most abundant carotenoid in bovine milk from cows fed common feeds (Nozière et al., 2006; Stout et al., 2018). Furthermore, carotenoids were shown to be responsible for about half of the variability of the milk yellowness index (Nozière et al., 2006). Likewise, spirulina was previously found to increase yellowness of chicken meat (Toyomizu et al., 2001), egg yolk (Anderson et al., 1991), and catfish skin (Liu et al., 2019). In these studies, xanthophylls were described to be responsible for the increased yel-

Table 7. Effect of spirulina supplementation on characteristics of rumen fluid and blood $(\mathrm{n}=6)$

\begin{tabular}{|c|c|c|c|c|}
\hline \multirow[b]{2}{*}{ Item } & \multicolumn{2}{|c|}{ Diet } & \multirow[b]{2}{*}{ SEM } & \multirow[b]{2}{*}{$P$-value } \\
\hline & Soybean meal & Spirulina & & \\
\hline \multicolumn{5}{|l|}{ Rumen fluid traits } \\
\hline $\mathrm{pH}$ & 7.22 & 7.04 & 0.073 & 0.125 \\
\hline Ammonia (mmol/L) & 4.87 & 6.38 & 0.692 & 0.164 \\
\hline Total VFA (mmol/L) & 136 & 101 & 7.8 & 0.020 \\
\hline \multicolumn{5}{|l|}{ Molar VFA proportions $(\mathrm{mmol} / \mathrm{mol})$} \\
\hline Acetate & 731 & 731 & 4.3 & 0.999 \\
\hline Propionate & 144 & 143 & 3.7 & 0.887 \\
\hline Isobutyrate & 5.94 & 4.24 & 0.818 & 0.192 \\
\hline Butyrate & 102 & 106 & 3.5 & 0.434 \\
\hline Isovalerate & 10.3 & 9.13 & 1.38 & 0.584 \\
\hline Valerate & 6.42 & 5.84 & 0.280 & 0.194 \\
\hline \multicolumn{5}{|l|}{ Molar ratios } \\
\hline Acetate/propionate & 5.09 & 5.11 & 0.148 & 0.928 \\
\hline (Acetate+butyrate)/propionate & 5.80 & 5.85 & 0.178 & 0.848 \\
\hline Total phenols $(\mathrm{mg} / \mathrm{L})$ & 347 & 371 & 16.6 & 0.345 \\
\hline \multicolumn{5}{|l|}{ Blood traits } \\
\hline$\alpha$-Tocopherol (mg/L) & 2.81 & 3.26 & 0.238 & 0.233 \\
\hline Total phenols (mg/L) & 199 & 190 & 6.8 & 0.369 \\
\hline Total antioxidant capacity $\left(\mathrm{m} M \mathrm{UA}_{\mathrm{Eq}}\right)^{1}$ & 0.259 & 0.264 & 0.0126 & 0.795 \\
\hline
\end{tabular}


lowness. The coloring effects may be a characteristic of spirulina as for instance, DHA-enriched microalgae were reported to have no effect on the sensory perception of cheese color (Till et al., 2019).

In the series of triangle tests performed, the trained panelists were not able to consistently distinguish between homogenized and pasteurized milk obtained from spirulina-fed cows and soybean meal-fed cows. This indicates that neither specific flavor notes nor off-flavors were generated by the inclusion of spirulina in the diet. In addition, this is in line with the relatively few differences we found in milk FA profile, whereby FA susceptible to oxidation such as n-3 and n- 6 long-chain PUFA were not increased in milk from spirulina-fed cows. Homogenization and pasteurization might have influenced milk color (Amador-Espejo et al., 2014) and thus possibly have diminished the visibility of differences in yellowness.

With regard to the milk coagulation properties, we observed no disadvantages of the inclusion of $5 \%$ spirulina in the diet. This is consistent with the absence of effects on milk protein and casein contents, main factors influencing milk coagulation (Macheboeuf et al., 1993). The firmness of butter and cheese depends on the FA profile (Bugaud et al., 2001). According to the observed unchanged calculated spreadability index (C18:1n-9 to $\mathrm{C} 16: 0$ ratio; Bugaud et al., 2001), cheese texture is not expected to differ with spirulina feeding. This may be different with other microalgae, as the effects on milk FA profile were reported to be different for other microalgae-based feeds (Lamminen et al., 2019a; Till et al., 2019). In the study of Till et al. (2019), cheeses were softer when cows were supplemented with $150 \mathrm{~g} / \mathrm{d}$ of a DHA-enriched product of Schizochytrium limacinum.

\section{CONCLUSIONS}

Spirulina was shown to be a suitable protein source to replace soybean meal in the diet of dairy cows. The inclusion of rather high levels of spirulina in the diet did not seem to affect the DM intake, thus disproving hypothesis 1, but reduced rumen fermentation, without negative consequences for milk yield and milk composition. The contents of $\beta$-carotene and the milk FA profile of the spirulina-fed cows were changed, but not milk coagulation properties, which only partially confirmed hypothesis 2 . The changes in milk FA profile indicated a slightly reduced ruminal biohydrogenation, and there was consequently a lower accumulation of biohydrogenation intermediates in milk. The content of phenols and the total antioxidant capacity in plasma and milk were not affected, thus disproving hypothesis 3. Unexpectedly, the milk sensory properties seemed not to have been affected by the inclusion of spirulina in the diet making compensatory effects not necessarily different from hypothesis 4 . Potential human healthrelated benefits of the milk from spirulina-fed cows were limited to elevated $\beta$-carotene and $\gamma$-linolenic acid levels. Testing spirulina supplementation with more cows and over an extended period might clarify if effects too weak to be determined with the limited replicates in the present study are nevertheless present and if the bioactive compounds in spirulina may have also an effect on individual cow and herd fertility.

\section{ACKNOWLEDGMENTS}

The authors are grateful to M. Hunziker, N. Spalinger and H. Renfer for the technical support during the experiment, E. Friedli for homogenizing and pasteurizing the milk, and C. Kunz, M. Mergani, and P. Bucher for the help with the laboratory analyses. The participation of the voluntary panelists in the sensory evaluation is gratefully acknowledged. We thank the three anonymous reviewers for their helpful comments on earlier drafts of the manuscript. The financial support of the H. Wilhelm Schaumann Foundation (Hamburg, Germany) is greatly appreciated. The authors have not stated any conflicts of interest.

\section{REFERENCES}

Abayasekara, D. R. E., and D. C. Wathes. 1999. Effects of altering dietary fatty acid composition on prostaglandin synthesis and fertility. Prostaglandins Leukot. Essent. Fatty Acids 61:275-287. https: //doi.org/10.1054/plef.1999.0101.

Agroscope. 2020. Feeding recommendations for ruminants (in German). Accessed on Jan. 24, 2020. https://www.agroscope .admin.ch/agroscope/de/home/services/dienste/futtermittel/ fuetterungsempfehlungen-wiederkaeuer.html.

Amador-Espejo, G. G., A. Suàrez-Berencia, B. Juan, M. E. Bárcenas, and A. J. Trujillo. 2014. Effect of moderate inlet temperatures in ultra-high pressure homogenization treatments on physicochemical and sensory characteristics of milk. J. Dairy Sci. 97:659-671. https: //doi.org/10.3168/jds.2013-7245.

Anderson, D. W., C. S. Tang, and E. Ross. 1991. The xanthophylls of Spirulina and their effect on egg yolk pigmentation. J. Poult. Sci. 70:115-119. https://doi.org/10.3382/ps.0700115.

AOAC International. 1997. Official Methods of Analysis.16th edition. Association of Official Analytical Chemists, Arlington, VA.

Becker, E. W. 2013. Microalgae in human and animal nutrition. Pages 461-503 in Handbook of Microalgal Culture: Applied Phycology and Biotechnology. 2nd ed. A. Richmond and H. Qiang, ed. John Wiley \& Sons, Hoboken, NJ.

Belury, M. A. 2002. Dietary conjugate linoleic acid in health: Physiological effects and mechanism of action. Annu. Rev. Nutr. 22:505531. https://doi.org/10.1146/annurev.nutr.22.021302.121842.

Bleakley, S., and M. Hayes. 2017. Algal proteins: Extraction, application, and challenges concerning production. Foods 6:33. https:// doi.org/10.3390/foods6050033.

Boeckaert, C., B. Vlaeminck, V. Fievez, L. Maignien, J. Dijkstra, and N. Boon. 2008. Accumulation of trans $\mathrm{C}_{18: 1}$ fatty acids in the rumen after dietary algal supplementation is associated with changes in the Butyrivibrio community. Appl. Environ. Microbiol. 74:69236930. https://doi.org/10.1128/AEM.01473-08. 
Bugaud, C., S. Buchin, J. B. Coulon, A. Hauwuy, and D. Dupont. 2001. Influence of the nature of alpine pastures on plasmin activity, fatty acid and volatile compound composition of milk. Lait 81:401-414. https://doi.org/10.1051/lait:2001140.

Calderón, F., D. Chauveau-Duriot, P. Pradel, B. Martin, B. Graulet, M. Doreau, and P. Nozière. 2007. Variations in carotenoids, vitamins $\mathrm{A}$ and $\mathrm{E}$, and color in cow's plasma and milk following a shift from hay diet to diets containing increasing levels of carotenoids and vitamin E. J. Dairy Sci. 90:5651-5664. https://doi.org/ $10.3168 / \mathrm{jds} .2007-0264$.

Christensen, R. H. B., and P. B. Brockhoff. 2020. sensR - An R-package for sensory discrimination. R-package version 1.5-1. Accessed January 2020. https://www.cran.r-project.org/package=sensR/.

Coppa, M., A. Ferlay, F. Monsallier, I. Verdier-Metz, P. Pradel, R. Didienne, A. Farruggia, M. C. Montel, and B. Martin. 2011. Milk fatty acid composition and cheese texture and appearance from cows fed hay or different grazing systems on upland pastures. J. Dairy Sci. 94:1132-1145. https://doi.org/10.3168/jds.2010-3510.

de Souza, R. J., A. Mente, A. Maroleanu, A. I. Cozma, V. Ha, T. Kishibe, E. Uleryk, P. Budylowski, H. Schünemann, J. Beyene, and S. S. Anand. 2015. Intake of saturated and trans unsaturated fatty acids and risk of all cause mortality, cardiovascular disease, and type 2 diabetes: Systematic review and meta-analysis of observational studies. BMJ 351:h3978. https://doi.org/10.1136/bmj .h3978.

DeVries, T. J., and R. M. Gill. 2012. Adding liquid feed to a total mixed ration reduces feed sorting behavior and improves productivity of lactating dairy cows. J. Dairy Sci. 95:2648-2655. https:// doi.org/10.3168/jds.2011-4965.

DIN EN 12823-2. 2000. Bestimmung von Vitamin A mit Hochleistungs-Flüssig-chromatographie. Bestimmung von $\beta$-Carotin (Teil 2). Deutsches Institut für Normung e.V. Berlin, Beuth Verlag GmbH, Berlin, Germany. https://www.beuth.de/de/norm/din-en $-12823-2 / 31427435$.

Ding, L., Y. Wang, M. Kreuzer, X. Guo, J. Mi, Y. Gou, Z. Shang, Y. Zhang, J. Zhou, H. Wang, and R. Long. 2013. Seasonal variations in the fatty acid profile of milk from yaks grazing on the Qinghai-Tibetan plateau. J. Dairy Res. 80:410-417. https://doi .org/10.1017/S0022029913000496.

Ehrlich, G. G., D. F. Goerlitz, J. H. Bourell, G. V. Eisen, and E. M. Godsy. 1981. Liquid chromatographic procedure for fermentation product analysis in the identification of anaerobic bacteria. Appl. Environ. Microbiol. 42:878-885. https://doi.org/10.1128/AEM.42 $.5 .878-885.1981$

Fan, Y. Y., and R. S. Chapkin. 1998. Importance of $\gamma$-linolenic acid in human health and nutrition. J. Nutr. 128:1411-1414. https://doi .org/10.1093/jn/128.9.1411.

Garcés, C. N., D. Vela, A. Mullo, V. Cabezas, A. Alvear, and C. H. Ponce. 2019. Spirulina supplementation during the transition period by grazing dairy cattle at tropical highland conditions. Trop. Anim. Health Prod. 51:477-480. https://doi.org/10.1007/s11250 $-018-1691-7$.

German, J. B., R. A. Gibson, R. M. Krauss, P. Nestel, B. Lamarche, W. A. Van Staveren, J. M. Steijns, L. C. P. G. M. De Groot, A. L. Lock, and F. Destaillats. 2009. A reappraisal of the impact of dairy foods and milk fat on cardiovascular disease risk. Eur. J. Nutr. 48:191-203. https://doi.org/10.1007/s00394-009-0002-5.

González López, C. V., M. C. C. García, F. G. A. Fernández, C. S. Bustos, Y. Chisti, and J. M F. Sevilla. 2010. Protein measurement of microalgal and cyanobacterial biomass. Bioresour. Technol. 101:7587-7591. https://doi.org/10.1016/j.biortech.2010.04.077.

Graulet, B., C. Cirié, and B. Martin. 2019. Contrasted effects of dietary extruded linseed supplementation on carotenoid and liposoluble vitamin status in lactating Holstein or Montbéliarde cows fed hay or corn silage. J. Dairy Sci. 102:6210-6225. https://doi .org/10.3168/jds.2018-16138.

Habib, M. A. B., M. Parvin, T. C. Huntington, and M. R. Hasan. 2008. A Review on Culture, Production and Use of Spirulina as Food for Humans and Feeds for Domestic Animals and Fish. FAO Fisheries and Aquaculture Circular No. 1034. FAO, Rome, Italy.
Halmemies-Beauchet-Filleau, A., A. Vanhatalo, V. Toivonen, T. Heikkilä, M. R. F. Lee, and K. J. Shingfield. 2014. Effect of replacing grass silage with red clover silage on nutrient digestion, nitrogen metabolism, and milk fat composition in lactating cows fed diets containing a 60:40 forage-to-concentrate ratio. J. Dairy Sci. 97:3761-3776. https://doi.org/10.3168/jds.2013-7358.

Hintz, H. F., H. Heitman Jr., W. C. Weir, D. T. Torell, and J. H. Meyer. 1966. Nutritive value of algae grown on sewage. J. Anim. Sci. 25:675-681. https://doi.org/10.2527/jas1966.253675x.

IUPAC (International Union of Pure and Applied Chemistry). 1987. Preparation of the fatty acid methyl esters. Pages 123-129 in IUPAC Standard Methods for the Analysis of Oils, Fats and Derivates. A. Dieffenbacher, W. D. Pocklington, ed. Blackwell Scientific Publications, Oxford, UK.

Jayanegara, A., M. Kreuzer, and F. Leiber. 2012. Ruminal disappearance of polyunsaturated fatty acids and appearance of biohydrogenation products when incubating linseed oil with alpine forage plant species in vitro. Livest. Sci. 147:104-112. https://doi.org/10 .1016/j.livsci.2012.04.009.

Kaewlamun, W., M. Okouyi, P. Humblot, M. Techakumphu, and A. A. Ponter. 2011. Does supplementing dairy cows with $\beta$-carotene during the dry period affect postpartum ovarian activity, progesterone, and cervical and uterine involution? Theriogenology 75:10291038. https://doi.org/10.1016/j.theriogenology.2010.11.010.

Kälber, T., J. S. Meier, M. Kreuzer, and F. Leiber. 2011. Flowering catch crops used as forage plants for dairy cows: Influence on fatty acids and tocopherols in milk. J. Dairy Sci. 94:1477-1489. https:/ /doi.org/10.3168/jds.2010-3708.

Kawashima, C., S. Nagashima, K. Sawada, F. J. Schweigert, A. Miyamoto, and K. Kida. 2010. Effect of $\beta$-carotene supply during close-up dry period on the onset of first postpartum luteal activity in dairy cows. Reprod. Domest. Anim. 45:e282-e287. https://doi .org/10.1111/j.1439-0531.2009.01558.x.

Kurd, F., and V. Samavati. 2015. Water soluble polysaccharide from Spirulina platensis: Extraction and in vitro anti-cancer activity. Int. J. Biol. Macromol. 74:498-506. https://doi.org/10.1016/j .ijbiomac.2015.01.005.

Lamminen, M., A. Halmemies-Beauchet-Filleau, T. Kokkonen, S. Jaakkola, and A. Vanhatalo. 2019a. Different microalgae species as a substitutive protein feed for soya bean meal in grass silage based dairy cow diets. Anim. Feed Sci. Technol. 247:112-126. https://doi .org/10.1016/j.anifeedsci.2018.11.005.

Lamminen, M., A. Halmemies-Beauchet-Filleau, T. Kokkonen, A. Vanhatalo, and S. Jaakkola. 2019b. The effect of partial substitution of rapeseed meal and faba beans with Spirulina platensis microalgae on milk production, nitrogen utilization, and amino acid metabolism of lactating dairy cows. J. Dairy Sci. 102:7102-7117. https://doi.org/10.3168/jds.2018-16213.

Lamminen, M., A. Halmemies-Beauchet-Filleau, T. Kokkonen, I. Simpura, S. Jaakkola, and A. Vanhatalo. 2017. Comparison of microalgae and rapeseed meal as supplementary protein in the grass silage based nutrition of dairy cows. Anim. Feed Sci. Technol. 234:295311. https://doi.org/10.1016/j.anifeedsci.2017.10.002.

Liu, C., H. Liu, W. Xu, D. Han, S. Xie, J. Jin, Y. Yang, and X. Zhu. 2019. Effects of dietary Arthrospira platensis supplementation on the growth, pigmentation, and antioxidation in yellow catfish $(\mathrm{Pel}$ teobagrus fulvidraco). Aquaculture 510:267-275. https://doi.org/10 .1016/j.aquaculture.2019.05.067.

Macheboeuf, D., J. B. Coulon, and P. D'Hour. 1993. Effect of breed, protein genetic variants and feeding on cow's milk coagulation properties. J. Dairy Res. 60:43-54. https://doi.org/10.1017/ S0022029900027333.

Madeira, M. S., C. Cardoso, P. A. Lopes, D. Coelho, C. Afonso, N. M. Bandarra, and J. A. M. Prates. 2017. Microalgae as feed ingredients for livestock production and meat quality: A review. Livest. Sci. 205:111-121. https://doi.org/10.1016/j.livsci.2017.09.020.

Michal, J. J., L. R. Heirman, T. S. Wong, B. P. Chew, M. Frigg, and L. Volker. 1994. Modulatory effects of dietary $\beta$-carotene on blood and mammary leukocyte function in periparturient dairy cows. J. Dairy Sci. 77:1408-1421. https://doi.org/10.3168/jds.S0022 -0302(94)77079-X. 
Moate, P. J., S. R. O. Williams, M. C. Hannah, R. J. Eckard, M. J. Auldist, B. E. Ribaux, J. L. Jacobs, and W. J. Wales. 2013. Effects of feeding algal meal high in docosahexaenoic acid on feed intake, milk production, and methane emissions in dairy cows. J. Dairy Sci. 96:3177-3188. https://doi.org/10.3168/jds.2012-6168.

Nagyová, A., M. Krajčovičova-Kudlačkova, and J. Klvanová. 2001. LDL and HDL oxidation and fatty acid composition in vegetarians. Ann. Nutr. Metab. 45:148-151. https://doi.org/10.1159/ 000046722

Nozière, P., B. Graulet, A. Lucas, B. Martin, P. Grolier, and M. Doreau. 2006. Carotenoids for ruminants: From forages to dairy products. Anim. Feed Sci. Technol. 131:418-450. https://doi.org/ 10.1016/j.anifeedsci.2006.06.018.

Ogawa, T., and G. Terui. 1970. Studies on the growth of Spirulina platensis. On the pure culture of Spirulina platensis. J. Ferment. Technol. 48:361-367.

Ötleş, S., and R. Pire. 2001. Fatty acid composition of Chlorella and Spirulina microalgae species. J. AOAC Int. 84:1708-1714. https:// doi.org/10.1093/jaoac/84.6.1708.

Palmquist, D. L., and H. R. Conrad. 1978. High fat rations for dairy cows. Effects on feed intake, milk and fat production, and plasma metabolites. J. Dairy Sci. 61:890-901. https://doi.org/10.3168/jds .S0022-0302(78)83667-4.

Papadopoulos, G., C. Goulas, E. Apostolaki, and R. Abril. 2002. Effects of dietary supplement of algae, containing polyunsaturated fatty acids, on milk yield and the composition of milk products in dairy ewes. J. Dairy Res. 69:357-365. https://doi.org/10.1017/ S0022029902005599.

Pohndorf, R. S., A. S. Camara, A. P. Q. Larrosa, C. P. Pinheiro, M. M. Strieder, and L. A. A. Pinto. 2016. Production of lipids from microalgae Spirulina sp.: Influence of drying, cell disruption and extraction methods. Biomass Bioenergy 93:25-32. https://doi.org/ 10.1016/j.biombioe.2016.06.020.

Póti, P., F. Pajor, A. Bodnár, K. Penksza, and P. Köles. 2015. Effect of micro-alga supplementation on goat and cow milk fatty acid composition. Chil. J. Agric. Res. 75:259-263. https://doi.org/10 .4067/S0718-58392015000200017.

Probst, L., L. Frideres, P. Pedersen, and F. Amato. 2015. Sustainable, Safe and Nutritious Food. New Nutrient Sources. Business Innovation Observatory. Accessed on Jan. 24, 2020. http://ec.europa.eu/ DocsRoom/documents/13424/attachments/1/translations

Sajilata, M. G., R. S. Singhal, and M. Y. Kamat. 2008. Fractionation of lipids and purification of $\gamma$-linolenic acid (GLA) from Spirulina platensis. Food Chem. 109:580-586. https://doi.org/10.1016/ j.foodchem.2008.01.005.

Schiano, A. N., W. S. Harwood, and M. A. Drake. 2017. A 100-year review: Sensory analysis of milk. J. Dairy Sci. 100:9966-9986. https: //doi.org/10.3168/jds.2017-13031.

Stout, M. A., D. M. Benoist, and M. A. Drake. 2018. Simultaneous carotenoid and vitamin analysis of milk from total mixed ration-fed cows optimized for xanthophyll detection. J. Dairy Sci. 101:49064913. https://doi.org/10.3168/jds.2017-13092.

Sugano, M., T. Ide, T. Ishida, and K. Yoshida. 1986. Hypocholesterolemic effect of gamma-linolenic acid as evening primrose oil in rats. Ann. Nutr. Metab. 30:289-299. https://doi.org/10.1159/ 000177206.

Till, B. E., J. A. Huntington, W. Posri, R. Early, J. Taylor-Pickard, and L. A. Sinclair. 2019. Influence of rate of inclusion of microalgae on the sensory characteristics and fatty acid composition of cheese and performance of dairy cows. J. Dairy Sci. 102:1093410946. https://doi.org/10.3168/jds.2019-16391.
Toyomizu, M., K. Sato, H. Taroda, T. Kato, and Y. Akiba. 2001. Effects of dietary spirulina on meat colour in muscle of broiler chickens. Br. Poult. Sci. 42:197-202. https://doi.org/10.1080/ 00071660120048447.

Ulbricht, T. L. V., and D. A. T. Southgate. 1991. Coronary heart disease: Seven dietary factors. Lancet 338:985-992. https://doi.org/ 10.1016/0140-6736(91)91846-M.

Van Soest, P. J., J. B. Robertson, and B. A. Lewis. 1991. Methods for dietary fiber, neutral detergent fiber, and nonstarch polysaccharides in relation to animal nutrition. J. Dairy Sci. 74:3583-3597. https://doi.org/10.3168/jds.S0022-0302(91)78551-2.

Wan, D., Q. Wu, and K. Kuča. 2016. Spirulina. Pages 569-583 in Nutraceuticals: Efficacy, Safety and Toxicity. R. Gupta, ed. Academic Press, Cambridge, MA.

Wild, K. J., H. Steingass, and M. Rodehutscord. 2018. Variability in nutrient composition and in vitro crude protein digestibility of 16 microalgae products. J. Anim. Physiol. Anim. Nutr. (Berl.) 102:1306-1319. https://doi.org/10.1111/.jpn.12953.

Wild, K. J., H. Steingass, and M. Rodehutscord. 2019. Variability of in vitro ruminal fermentation and nutritional value of cell-disrupted and nondisrupted microalgae for ruminants. Glob. Change Biol. Bioenergy 11:345-359. https://doi.org/10.1111/gcbb.12539.

\section{ORCIDS}

M. Kreuzer (ํ) https://orcid.org/0000-0002-9978-1171

K. Giller @ https://orcid.org/0000-0002-1276-4548

\section{APPENDIX}

Table A1. Effect of spirulina supplementation on proportions of short- and medium-chain fatty acids in milk fat (\% of total FAME)

\begin{tabular}{|c|c|c|c|c|}
\hline \multirow[b]{2}{*}{ Item } & \multicolumn{2}{|c|}{ Diet } & \multirow[b]{2}{*}{ SEM } & \multirow[b]{2}{*}{$P$-value } \\
\hline & $\begin{array}{c}\text { Soybean } \\
\text { meal }\end{array}$ & Spirulina & & \\
\hline $\mathrm{C} 4: 0$ & 1.603 & 1.528 & 0.066 & 0.450 \\
\hline C6:0 & 1.762 & 1.589 & 0.052 & 0.058 \\
\hline $\mathrm{C} 8: 0$ & 0.048 & 0.053 & 0.0018 & 0.074 \\
\hline C10:0 & 3.349 & 3.072 & 0.148 & 0.233 \\
\hline C12:0 & 4.179 & 3.857 & 0.249 & 0.396 \\
\hline $\mathrm{C} 12: 0$ iso & 0.140 & 0.111 & 0.0127 & 0.157 \\
\hline $\mathrm{C} 13: 0$ & 0.125 & 0.133 & 0.0105 & 0.595 \\
\hline $\mathrm{C} 13: 0$ iso & 0.203 & 0.256 & 0.0224 & 0.145 \\
\hline $\mathrm{C} 14: 0$ & 13.26 & 13.47 & 0.334 & 0.668 \\
\hline $\mathrm{C} 14: 0$ iso & 0.011 & 0.008 & 0.0019 & 0.327 \\
\hline C14:0 anteiso & 0.711 & 0.829 & 0.0487 & 0.138 \\
\hline C15:0 & 1.579 & 1.695 & 0.068 & 0.274 \\
\hline $\mathrm{C} 15: 0$ iso & 0.028 & 0.036 & 0.0029 & 0.096 \\
\hline cis-9 C10:1 & 0.430 & 0.352 & 0.0299 & 0.112 \\
\hline cis-9 C12:1 & 0.143 & 0.113 & 0.0140 & 0.179 \\
\hline cis-9 C14:1 & 1.676 & 1.443 & 0.143 & 0.292 \\
\hline cis-9-C15:1 & 0.353 & 0.417 & 0.0228 & 0.094 \\
\hline
\end{tabular}

